\title{
ANALISIS KONTRIBUSI PERUSAHAAN DAERAH PASAR TERHADAP PENINGKATAN PENDAPATAN ASLI DAERAH DI KABUPATEN LAMONGAN
}

\author{
*(Edie Sugiarto \\ Prodi Manajemen, Fakultas Ekonomi, Universitas Islam Lamongan \\ $\mathrm{Jl}$. Veteran No.53A Lamongan \\ Telp. ( 0322 ) 324706, Faks. ( 0322 ) 324706 \\ Email :jpim.unisla@gmail.com
}

\begin{abstract}
ABSTRAK
Hasil perusahaan milik daerah dan hasil pengelolaan kekayaan daerah yang dipisahkan. Hasil perusahaan milik daerah merupakan pendapatan daerah dari keuntungan bersih perusahaan daerah yang berupa dana pembangunan daerah dan bagian untuk anggaran belanja daerah yang disetor ke kas daerah, baik perusahaan daerah yang dipisahkan, sesuai dengan motif pendirian dan pengelolaan, maka sifat perusahaan dareah adalah suatu kesatuan produksi yang bersifat menambah pendapatan daerah, memberi jasa, dan memperkembangkan perekonomian daerah. Hasil penelitian menunjukkan Pada tahun 2010 didapat kriteria relatif tidak berkontribusi Senilai 0\% dengan laba Senilai 1.423.787.157,88Pada tahun 2011 didapat kriteria kurang berkontribusi senilai $1,57 \%$ dengan laba senilai 207.699.303,00 dibagi dengan total laba penyertaan modal pada PAD senilai 13.248.936.779,00.Pada tahun 2012 didapat kontribusi senilai 3,03 \% dengan laba senilai 487.308.807,00 dibagi dengan total laba penyertaan modal pada PAD senilai 16.040.602.352,00.Menglami penurunan di tahun 2013 dengan kriteria relative tidak berkontribusi senilai 0,97\% dengan laba senilai 149.591.500,00 dibagi dengan total laba penyertaan modal pada PAD senilai 15.389.749.772,00.Terjadi peningkatan kembali yang besar ditahun 2014 dengan kriteria kurang berkontribusi senilai 1,75\% dengan laba senilai 283.193.096,00 dibagi dengan total laba penyertaan modal pada PAD senilai 16.091.497.784,00.
\end{abstract}

Kata Kunci : Laba PD.Pasar Kab.Lamongan, Laba Penyertaan Modal BUMD, Pendapatan Asli Daerah.

\section{PENDAHULUAN}

Semua sumber keuangan yang melekat pada setiap urusan Pemerintah yang diserahkan kepada Daerah menjadi sumber keuangan. Daerah diberikan hak untuk mendapatkan sumber keuangan antara lain berupa : a. Kepastian tersedianya pendanaan dari Pemerintah sesuai dengan urusan pemerintah yang diserahkan, b.Kewenangan memungut dan mendayagunakan pajak dan retribusi daerah dan hak bagi mendapatkan bagi hasil dari sumber daya nasional yang berada didaerah dan dana perimbangan lainnya, c. Hak untuk mengelola kekayaan daerah dan mendapatkan sumber- sumber pendapatan lain yang sah serta sumber-sumber pembiayaan. Pendapatan Asli Daerah (PAD) adalah salah satu sumber penerimaan yang harus selalu terus menerus di pacu pertumbuhannya, yang pemungutannya berdasarkan peraturan undang-undang ( Yani ; 2002). Menurut Halim (2004:67), 
"Pendapatan Asli Daerah (PAD) merupakan semua penerimaan daerah yang berasal dari sumber ekonomi asli daerah. Pasal 157 UU No. 32 Tahun 2004 dan Pasal 6 UU No. 33 Tahun 2004 menjelaskan bahwa sumber Pendapatan Asli Daerah (PAD) terdiri ; (1) Pajak daerah, (2) Retribusi daerah, (3) hasil pengelolaan kekayaan daerah yang dipisahkan, serta (4) Lain-lain Pendapatan Asli Daerah (PAD) yang sah. Sedangkan menurut (Mahmudi ; 2010) menyatakan bahwa kemandirian keuangan daerah diukur melalui Pendapatan Asli Daerah (PAD) yang meliputi ; pajak daerah, retribusi daerah, laba BUMD serta pendapatan lain-lain yang sah.

Berdasarkan latar belakang diatas dapat diambil rumusan sebagai berikut :

Bagaimana Kontribusi Laba PD.Pasar terhadap Peningkatan Pendapatan Asli Daerah di Kabupaten Lamongan?

Adapun tujuan yang ingin dicapai dari penelitian ini adalah :

Untuk mengetahui kontribusi Laba PD.PASAR terhadap Peningkatan Pendapatan Asli Daerah di Kabupaten Lamongan.

Undang-Undang No.5 Tahun 1962 tentang Perusahaan Daerah memberikan pengertian tentang yang dimaksud dengan Perusahaan Daerah adalah semua perusahaan yang didirikan berdasarkan undang-undang ini yang seluruh atau sebagian modalnya merupakan kekayaan daerah yang dipisahkan, kecuali jika ditentukan lain dengan atau berdasarkan undang-undang."

Sedangkan menurut Undang-Undang RI Nomor 17 Tahun 2003 tentang Keuangan Negara yang dimaksud dengan Perusahaan Daerah "adalah badan usaha yang seluruh atau sebagian modalnya diimiliki oleh Pemerintah Daerah".
Menurut Elita Dewi (2002:4) mengenai perusahaan daerah adalah sebagai berikut :

1. Perusahaan Daerah adalah kesatuan produksi yang bersifat: Memberi jasa, Menyelenggarakan pemanfaatan umum, Memupuk pendapatan.

2. Tujuan perusahaan daerah untuk turut serta melaksanakan pembangunan daerah khususnya dan pembangunan kebutuhan rakyat dengan menggutamakan industrialisasi dan ketentraman serta ketenangan kerja menuju masyarakat yang adil dan makmur.

3. Perusahaan daerah bergerak dalam lapangan yang sesuai dengan urusan rumah tangganya menurut perundang-undangan yang mengatur pokok-pokok pemerintahan daerah.

4. Cabang-cabang produksi yang penting bagi daerah dan mengusai hajat hidup orang banyak di daerah, yang modal untuk seluruhnya merupakan kekayaan daerah yang dipisahkan Selanjutnya Digital Library (www.google.co.id).

diakses tanggal 25 juli 2008) menyebutkan Perusahaan Daerah adalah: "Suatu kesatuan produksi yang bersifat memberi jasa, menyelenggarakan kemanfaatan umum dan memupuk pendapatan. Perusahaan Daerah dipimpin oleh suatu Direksi yang jumlah anggota dan susunannya ditetapkan dalam peraturan pendiriannya. Direksi berada dibawah pengawasan Kepala Daerah/pemegang saham/saham prioritet atau badan yang ditunjuknya".

Sementara

Glosarium Departemen Dalam Negeri (www.depdagri.co.id) diakses tanggal 23 juli 2008) menjelaskan bahwa "Perusahaan yang pendiriannya 
diprakarsai oleh Pemerintah Daerah yang modalnya untuk seluruhnya atau untuk sebagian merupakan kekayaan daerah yang dipisahkan". Undangundang Nomor 5 Tahun 1962 tentang Perusahaan daerah telah memberikan pengertian tentang perusahaan daerah, dimana dititik beratkan kepada faktor permodalan yang dinyatakan untuk seluruhnya atau sebagiannya merupakan kekayaan daerah yang dipisahkan. Seperti yang disebutkan dalam Pasal 2 bahwa "Perusahaan daerah ialah semua perusahaan yang didirikan berdasarkan Undang-Undang ini yang modalnya untuk seluruhnya atau sebagian merupakan kekayaan daerah yang dipisahkan, kecuali jika ditentukan lain dengan atau berdasarkan Undang-Undang". Ini berarti bahwa masih ada kemungkinan mengikutsertakan swasta ke dalam perusahaan, dan ini sesuai pula dengan dasar-dasar pemikiran bahwa segala modal yang ada dalam masyarakat yang merupakan pengerahan potensi dana dan tenaga (funds and forces) dapat diikutsertakan. Sedangkan berdasarkan Keputusan Menteri Dalam negeri dan Otoda Nomor 43 Tahun 2000 tentang Pedoman Kerjasama Perusahaan Daerah dengan Pihak Ketiga Pasal 1, menetapkan bahwa: "Perusahaan daerah adalah semua badan usaha yang modalnya merupakan kekayaan daerah yang dipisahkan dan pendiriannya diprakarsai oleh daerah". Mannulang dalam Hessel Nogi S.T ( 2005:75) menyatakan bahwa "Perusahaan daerah adalah suatu badan yang dibentuk oleh daerah untuk mengembangkan perekonomian dan untuk menambah penghasilan daerah, di mana tujuan utama perusahaan daerah bukan pada keuntungan, akan tetapi justru memberikan jasa dan menyelenggarakan jasa umum serta mengembangkan perekonomian daerah, sehingga dengan deimikian perusahaan daerah mempunyai fungsi ganda yang harus menjamin keseimbangan antara fungsi sosial dan fungsi ekonomis". Ciri-ciri perusahaan daerah menurut Muh. Bakat, dkk. (1989:104) adalah:

1. Didirikan dengan suatu peraturan daerah.

2. Modal seluruhnya atau sebagian merupakan kekayaan daerah yang dipisahkan, kecuali bila ada ketentuan lain berdasarkan undangundang.

3. Tujuan usaha adalah mencari laba untuk dana pembangunan daerah.

4. Dipimpin oleh suatu direksi yang diatur dalam peraturan pendiriannya.

5. Ada dewan perusahaan daerah yang tugas dan wewenangnya diatur dalam peraturan pemerintah.

6. Kekuasaan tertinggi bukan pada rapat pemegang saham tetapi dalam beberapa hal pada kepala daerah.

\section{LANDASAN TEORI}

Menurut Perda Kabupaten Lamongan No.6 Tahun 2008 tentang Perusahaan Daerah Pasar Kabupaten Lamongan Bahwa dalam rangka lebih meningkatkan potensi dan fungsi pasar untuk meningkatkan pertumbuhan ekonomi dan pendapatan asli daerah serta guna meningkatkan pelaksanaan pembangunan di daerah Kabupaten Lamongan, maka diperlukan lembaga dengan pola manajemen yang tepat dan professional yang dapat memberikan fasilitas perpasaran dan mampu mencukupi konsumsi masyarakat terhadap barang-barang kebutuhan rumah tangga maupun barang dagangan lainnya.

Perusahaan Daerah merupakan bentuk badan usaha yang layak untuk melaksanakan pengelolaan pasar dengan manajemen yang tepat dan profesional, mengingat perkembangan 
pasar dari tahun ke tahun selalu mengalami peningkatan, sehingga untuk mewadahi perkembangan pasar dimaksud diperlukan sistem kerja yang berlaku bagi perusahaan, sedangkan tujuan normatif yang hendak dicapai meliputi peningkatan pendapatan dan peningkatan usaha. Sehubungan dengan hal tersebut dengan telah ditetapkannya Peraturan Pemerintah Nomor 41 Tahun 2007 tentang Organisasi Perangkat Daerah, bahwa "pengelolaan pasar" tidak masuk dalam perumpunan dinas teknis maupun lembaga teknis daerah maka Kantor Pengelolaan Pasar Kabupaten Lamongan yang dibentuk dengan Peraturan Daerah Kabupaten Lamongan Nomor 8 Tahun 2003 tentang Organisasi dan Tata Kerja Kantor Pengelolaan Pasar Kabupaten Lamongan diubah menjadi Perusahaan Daerah Pasar Kabupaten Lamongan.

Modal dasar yang diberikan Pemerintah Daerah ditetapkan sebesar Rp.175.000.000.000 sebagaimana Peraturan Daerah Nomor 11 tahun 2010 merupaka kekayaan daerah yang dipisahkan. Unit - unit nya terdiri atas, unit Pasar Lamongan Baru dan PPKL, Pasar Sidoharjo, Pasar Ikan, Pasar Blimbing/Brondong, Pasar Hewan, Pasar Maduran, Pasar Lamongan Plaza, Pasar Babat, Pasar Agrobis Babat.

Program pencapaian dan peningkatan pendapatan pasar meliputi:

1. Meningkatkan pendapatan Retribusi parkir.

2. Meningkatkan retribusi pelayanan pasar.

3. Meningkatkan retribusi jasa usaha (sewa toilet).

4. Meningkatkan Lamongan Plaza

Dalam rangka upaya pengembangan perusahaan, telah dibuat berbagai terobosan baru dengan harapan dapat menarik minat pengusaha untuk berinvestasi di Lamongan, antara lain :

1. Pengembangan Dept.Store di Lamongan Plaza.

2. Pembangunan dan rehabilitasi pasar tradisional menjadi pasar tradisional yang bersih, aman, dan nyaman.

3. Pendampingan bagi pedagang pasar tradisional.

4. Penataan dan pembinaan pedagang pasar tradisional.

5. Perbaikan jaringan suplai barang ke pedagang pasar

Sedangkan unsur-unsur yang mendukung dalam pengelolaan jangka panjang yaitu :

1. Terwujudnya tertib administrasi.

2. Terwujudnya peningkatan retribusi dan lain-lain (PAD.)

3. Meningkatnya sumber daya manusia (SDM) pengeloa Pasar.

4. Meningkatnya pengembangn fungsi pasar.

Menurut perda No.6 tahun 2008 tentang Perusahaan Daerah Pasar Kabupaten Lamongan Pasal 32 Ayat 1 menerangkan bahwa Laba bersih Perusahaan Daerah setelah dipotong pajak yang telah disahkan oleh Kepala Daerah ditetapkan sebagai berikut :

a. bagian laba untuk daerah $55 \%$

b. cadangan umum $15 \%$

c. dana kesejahteraan $20 \%$

d. jasa sosial dan pendidikan $10 \%$ visi : menciptakan pasar yang aman, tertib, bersih dan menguntungkan misi :

1. Meningkatkan kemampuan pengelolaan pasar

2. Meningkatkan kotribusi PAD dengan mengoptimalkan sumbersumber pendapatan pasar

3. Meningkatkan sarana dan prasarana pasar

4. Mengembangkan informasi pasar

5. Memenuhi barang dan jasa lengkap,segar,murah dan bersaing 
Unit Pasar :

1. Unit pasar PPKL/Lamongan Baru

2. Unit Pasar sidoharjo

3. Unit Pasar Ikan

4. Unit Pasar Babat

5. Unit Pasar Hewan

6. Unit Pasar Blimbing/Brondong

7. Unit Pasar Maduran

8. Unit Pasar Lamongan Plaza

9. Unit Pasar Modern

\section{METODE PENELITIAN Spesifikasi Penelitian}

Penelitian Kualitatif ini bersifat deskriptif analitis, deskriptif yaitu menggambarkan atau menguraikan sesuatu secara utuh dalam bentuk tulisan, dengan menyelidiki data-data kualitatif yang berupa tabel pedapatan / laba bersih Perusahaan Daerah Kabupaten Lamongan. Sedang analitis yaitu menganalisa, mengupas secara tersistem atau terstruktur dan teratur sehingga dapat diambil kesimpulan bahwa deskriptif analitis yaitu penelitian yang mengambarkan atau menguraikan sesuatu secara utuh dalam bentuk tulisan yang dianalisis atau diuraikan secara sistematis.

\section{Populasi dan Sampel}

\section{Populasi}

Suharsimi Arikunto (2001: 15) Populasi adalah serangkaian atau sekumpulan subyek yang mempunyai satu atau lebih, ciri-ciri menonjol dalam satuan obyek. Populasi menurut sugiono (2005 : 55) adalah wilayah generalisasi yang terdiri atas obyek atau subyek yang mempunyai kuantitas dan karakteristik tertentu yang ditetapkan oleh penelitian untuk dipelajari dan kemudian ditarik kesimpulan. Populasi dalam penelitian ini adalah hasil pengelolaan kekayaan daerah yang dipisahkan berupa Laba Penyertaan Modal BUMD yang dilihat dari Laporan Pendapatan Asli Daerah
Kabupaten Lamongan tahun 2010 2014.

\section{Sampel}

Suharsimi Arikunto (2001 : 17) sampel secara sederhana dapat didefinisikan secara obyek, wilayah atau peristiwa yang akan dijadikan sebagai cerminan obyek penelitian dengan karakteristik dan ciri-ciri yang sesuai dengan populasi. Sampel yang diambil dalam penelitian ini adalah PD.Pasar Kab. Lamongan. Dengan pengamatan pada Laporan Pendapatan atau Laba penyertaan modal PD.Pasar tahun 2010 - 2014.

\section{Teknik sampling}

Penentuan sampel dalam penelitian ini dilakukan dengan menggunakan teknik non-random sampling atau Purposive Sampling. Yaitu peneliti mengambil subyek yang didasarkan pada tujuan tertentu untuk mengkaji kontribusi hasil perusahaan milik daerah (pendapatan perusahaan Daerah), efektivitas dan tingkat pertumbuhan pendapatan perusahaan daerah kabupaten Lamongan yang mempengaruhi PAD.

\section{Analisis Data}

\section{Analisis Kontribusi}

Untuk kotribusi adalah dengan menggunakan alat analisis yang digunakan untuk mengetahui seberapa besar kontribusi yang disumbangkan oleh perusahaan daerah terhadap Pendapatan Asli Daerah (PAD). Berikut langkah untu menghitung kontribusi penerimaan laba perusahaan daerah :

a. Membagi penerimaan laba BUMD dengan Total Pendapatan Asli Daerah.

b. Setelah diperoleh pembagian dikalikan $100 \%$.

c. Hasil prosentase yang didapatkan kemudian dibandingkan dengan kontribusi. 
Untuk menjawab permasalahan, penulis menggunakan rumus :

Kontribusi Laba BUMD =

\section{Penerimaan Laba BUMD}

$\overline{\text { Total Pendapatan asli daerah }}$

Pendapatan Asli Daerah Setelah diperoleh hasil perbandingan maka kemudian dibandingkan dengan kriteria menurut Fuad Bawazier (1999 : 103) sebagai berikut :

\section{Tabel 1.}

Hasil Presentasi

\begin{tabular}{|c|c|l|}
\hline NO & PROSENTASE & \multicolumn{1}{|c|}{ KRITERIA } \\
\hline 1. & $0-0,9 \%$ & $\begin{array}{l}\text { Relatif tidak } \\
\text { mempuyai } \\
\text { kotribusi }\end{array}$ \\
\hline 2. & $1-1,9 \%$ & $\begin{array}{l}\text { Kurang mempuyai } \\
\text { Kontribusi }\end{array}$ \\
\hline 3. & $2-2.9 \%$ & $\begin{array}{l}\text { Cukup Mempunyai } \\
\text { Kontribusi }\end{array}$ \\
\hline 4. & $3-3,9 \%$ & $\begin{array}{l}\text { Mempunyai } \\
\text { Kontribusi }\end{array}$ \\
\hline 5. & $>4 \%$ & $\begin{array}{l}\text { Sangat } \\
\text { berkontribusi }\end{array}$ \\
\hline
\end{tabular}

Sumber : Pendapatan Asli Daerah Kabupaten Lamongan

\section{A. Tahapan Kegiatan Penelitian}
a. Koordinasi dengan instansi terkait
b. Pengumpulan data primer dan data sekunder
c. Membuat kajian
d. Wawancara dengan petugas
e. Analisis kajian
f. Laporan akhir hasil kajian

\section{HASIL PENELITIAN DAN PEMBAHASAN}

PD. Pasar Kabupaten Lamongan
Untuk Perusahaan Daerh Pasar Kabupaten Lamongan, untuk tahun 2010 - 2014, belum memberikan kontribusi pada Pendapatan Asli Daerah Kabupaten Lamongan, sebab untuk 5 tahun terakhir

Tabel 2.

Hasil kontribusi Laba PD.PASAR Tahun 2010-2014

\begin{tabular}{|c|c|c|c|c|}
\hline $\begin{array}{c}\text { Tah } \\
\text { un }\end{array}$ & $\begin{array}{c}\text { Laba } \\
\mathbf{( 2 )}\end{array}$ & $\begin{array}{c}\text { Total Laba } \\
\text { Penyertaan } \\
\text { Modal BUMD } \\
\mathbf{( 3 )}\end{array}$ & $\begin{array}{c}\mathbf{\%} \\
\mathbf{( 2 / 3 )}\end{array}$ & Kriteria \\
\hline 2010 & 0 & $1.423 .787 .157,88$ & $0 \%$ & $\begin{array}{c}\text { Relatif tidak } \\
\text { berkontribusi }\end{array}$ \\
\hline 2011 & $207.699 .303,00$ & $13.248 .936 .779,00$ & 1,57 & $\begin{array}{c}\text { Kurang } \\
\text { berkontribusi }\end{array}$ \\
\hline 2012 & $487.308 .807,00$ & $16.040 .602 .352,00$ & 3.03 & $\begin{array}{c}\text { Mempuyai } \\
\text { kontribusi }\end{array}$ \\
\hline 2013 & $149.591 .500,00$ & $15.389 .749 .772,00$ & 0,97 & $\begin{array}{c}\text { Relatif tidak } \\
\text { berkontribusi }\end{array}$ \\
\hline 2014 & $283.193 .096,00$ & $16.091 .497 .784,00$ & 1,75 & $\begin{array}{c}\text { Kurang } \\
\text { berkontribusi }\end{array}$ \\
\hline
\end{tabular}

Sumber : Pendapatan Asli daerah Kabupaten Lamongan

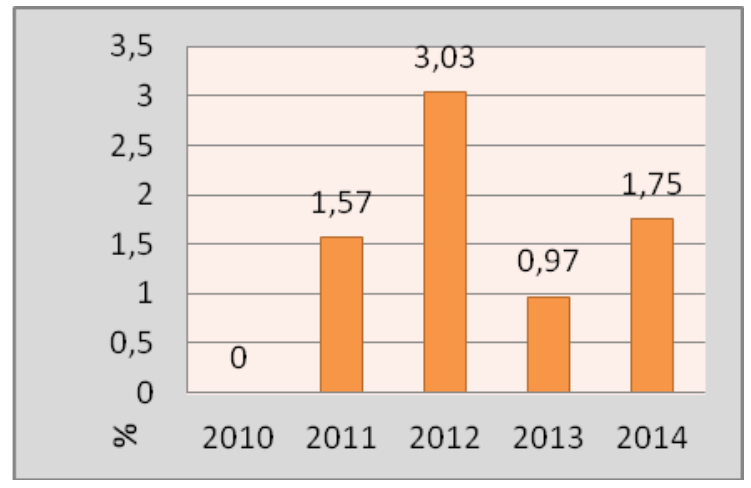

Gambar 1.

Grafik Hasil kontribusi Laba PD.Pasar tahun $2010-2014$

Dari peritungan tabel diatas dapat diketahui :

a. Pada tahun 2010 didapat kriteria relatif tidak berkontribusi Senilai $0 \%$ dengan laba Senilai 1.423.787.157,88

b. Pada tahun 2011 didapat kriteria kurang berkontribusi senilai $1,57 \%$ dengan laba senilai 207.699.303,00 dibagi dengan total laba penyertaan modal pada PAD senilai 13.248.936.779,00. 
c. Pada tahun 2012 didapat kontribusi senilai 3,03\% dengan laba senilai 487.308.807,00 dibagi dengan total laba penyertaan modal pada PAD senilai 16.040.602.352,00.

d. Menglami penurunan di tahun 2013 dengan kriteria relative tidak berkontribusi senilai 0,97\% dengan laba senilai 149.591.500,00 dibagi dengan total laba penyertaan modal pada PAD senilai 15.389.749.772,00.

e. Terjadi peningkatan kembali yang besar ditahun 2014 dengan kriteria kurang berkontribusi senilai $1,75 \%$ dengan laba senilai 283.193.096,00 dibagi dengan total laba penyertaan modal pada PAD senilai 16.091.497.784,00.

f. PD. Pasar

Dalam mengukur kinerja Perusahaan Daerah Pasar Lamongan maka perlu perhitungan rasio agar bisa menilai baik dan buruknya perusahaan tersebut dan mampu atau tidaknya perusahaan tersebut menaikkan laba.

Tabel 3.

Pertumbuhan Kinerja Keuangan Perusahaan Daerah Pasar Lamongan Tahun 2010 - 2014

\begin{tabular}{|c|c|c|c|c|c|c|}
\hline $\begin{array}{l}\mathbf{N} \\
\mathbf{0}\end{array}$ & Potensi & 2010 & 2011 & 2012 & 2013 & 2014 \\
\hline 1 & Asset & $\begin{array}{l}166.4 \\
66.41 \\
3,480\end{array}$ & $\begin{array}{l}163.3 \\
03.45 \\
5.895\end{array}$ & $\begin{array}{l}164.5 \\
29.07 \\
0.788 \\
\end{array}$ & $\begin{array}{l}165.2 \\
67.02 \\
4.000\end{array}$ & $\begin{array}{l}164.5 \\
88.82 \\
3.653\end{array}$ \\
\hline 2 & $\begin{array}{l}\text { Kewaji } \\
\text { ban }\end{array}$ & $\begin{array}{l}55.24 \\
9.500\end{array}$ & $\begin{array}{l}81.47 \\
7.313\end{array}$ & $\begin{array}{c}1.699 . \\
619.7 \\
13\end{array}$ & $\begin{array}{c}2.130 . \\
529.0 \\
00\end{array}$ & $\begin{array}{c}1.190 . \\
142.0 \\
18\end{array}$ \\
\hline 3 & Modal & $\begin{array}{l}166.4 \\
11.16 \\
3.800 \\
\end{array}$ & $\begin{array}{l}163.2 \\
21.97 \\
8.582 \\
\end{array}$ & $\begin{array}{l}162.8 \\
29.07 \\
0.788 \\
\end{array}$ & $\begin{array}{l}163.1 \\
36.49 \\
5.000 \\
\end{array}$ & $\begin{array}{l}163.3 \\
98.68 \\
1.635 \\
\end{array}$ \\
\hline 4 & $\begin{array}{l}\text { Pendap } \\
\text { atan } \\
\text { Usaha }\end{array}$ & $\begin{array}{c}4.276 \\
.948 . \\
900 \\
\end{array}$ & $\begin{array}{c}5.061 . \\
555.2 \\
53\end{array}$ & $\begin{array}{c}3.787 . \\
950.0 \\
61 \\
\end{array}$ & $\begin{array}{c}5.501 . \\
809.0 \\
00\end{array}$ & $\begin{array}{c}6.040 . \\
069.2 \\
51\end{array}$ \\
\hline 5 & $\begin{array}{l}\text { Biaya } \\
\text { Langsu } \\
\text { ng } \\
\text { Usaha } \\
\end{array}$ & $\begin{array}{c}932.2 \\
49.00 \\
0\end{array}$ & $\begin{array}{c}1.079 . \\
157.8 \\
50\end{array}$ & $\begin{array}{c}1.149 . \\
652.9 \\
00\end{array}$ & $\begin{array}{c}1.458 . \\
458.0 \\
00\end{array}$ & $\begin{array}{c}1.903 . \\
568.3 \\
00\end{array}$ \\
\hline 6 & $\begin{array}{l}\text { Biaya } \\
\text { Umum } \\
\& \\
\text { Admini } \\
\text { strasi }\end{array}$ & $\begin{array}{c}2.918 \\
.934 . \\
870\end{array}$ & $\begin{array}{c}3.096 . \\
646.8 \\
86\end{array}$ & $\begin{array}{c}2.401 . \\
679.6 \\
06\end{array}$ & $\begin{array}{c}3.622 . \\
742.0 \\
00\end{array}$ & $\begin{array}{c}3.925 . \\
019.8 \\
79\end{array}$ \\
\hline 7 & $\begin{array}{l}\text { Laba } \\
\text { (Rugi) }\end{array}$ & $\begin{array}{l}377.6 \\
35.00\end{array}$ & $\begin{array}{l}886.0 \\
16.01\end{array}$ & $\begin{array}{l}271.9 \\
84.50\end{array}$ & $\begin{array}{l}514.8 \\
90.00\end{array}$ & $\begin{array}{l}545.3 \\
79.41\end{array}$ \\
\hline
\end{tabular}

\begin{tabular}{|l|l|l|l|l|l|l|}
\hline & $\begin{array}{l}\text { Setelah } \\
\text { Pajak }\end{array}$ & 0 & 3 & 2 & 0 & 6 \\
\hline
\end{tabular}

Sumber : PD. Pasar Kabupaten

Lamongan

Dilihat dari table pertumbuhan kinerja keuangan diatas dapat diperoleh hasil bahwa setiap tahun dimulai tahun 2010 sampai dengan tahun 2014 PD.Pasar mengalami sebuah kenaikan dan penurunan dalam keuangan yang cukup signifikan sehingga tidak sampai mengalami kerugian.

Tabel 4.

Kriteria penilaian kesehatan perusahaan

\begin{tabular}{|c|l|c|}
\hline No & \multicolumn{1}{|c|}{ Kategori } & Kriteria \\
\hline 1. & Sehat & $>12 \%$ \\
\hline 2. & Cukup sehat & $8-12 \%$ \\
\hline 3. & Kurang Sehat & $5-8 \%$ \\
\hline 4. & Tidak Sehat & $<5 \%$ \\
\hline
\end{tabular}

Sumber: PD. Pasar Kabupaten

Lamongan

Kriterian Keuangan $=$

$\frac{\text { Laba Bersih Setelah pajak }}{\text { Pendapatan }} \times 100 \%$ $\frac{377.635 .000}{4.276 .948 .900} \times 100 \%=8,82 \%$

Tahun $2011=$

$$
\frac{886.016 .013}{5.061 .555 .253} \times 100 \%=17,51 \%
$$

Tahun $2012=$

$$
\frac{271.984 .502}{3.787 .950 .061} \times 100 \%=7,19 \%
$$

Tahun $2013=$

$$
\frac{514.890 .000}{5.501 .809 .000} \times 100 \%=9,36 \%
$$

Tahun $2014=$

$\frac{545.379 .416}{6.040 .069 .251} \times 100 \%=9,03 \%$ 
Dapat dikatakan bahwa perusahaan PD.Pasar di tahun 2010 perusahaan dalam kategori cukup sehat dan di tahun 2011 perusahaan ini dalam kategori sehat, karena pendapatannya lebih besar dari beban beban lain yang dikeluarkan, namun di tahun 2012 mengalami penurunan dengan kategori kurang sehat, tetapi di tahun 2013 dan tahun 2014 mengalami kenaikan yang cukup signifikan dengan kategori cukup sehat, dikarenakan pendapatan menurun dan beban usaha yang dibayarkan semakin meningkat.

\section{KESIMPULAN DAN SARAN Kesimpulan}

Dari hasil penelitian dan hasil analisis data dapat diambil kesimpulan sebagai berikut :

Pada tahun 2010 didapat kriteria relatif tidak berkontribusi Senilai $0 \%$ dengan laba Senilai 1.423.787.157,88Pada tahun 2011 didapat kriteria kurang berkontribusi senilai $1,57 \%$ dengan laba senilai 207.699.303,00 dibagi dengan total laba penyertaan modal pada PAD senilai 13.248.936.779,00.Pada tahun 2012 didapat kontribusi senilai 3,03\% dengan laba senilai 487.308.807,00 dibagi dengan total laba penyertaan modal pada PAD senilai 16.040.602.352,00.Menglami

penurunan di tahun 2013 dengan kriteria relative tidak berkontribusi senilai $0,97 \%$ dengan laba senilai 149.591.500,00 dibagi dengan total laba penyertaan modal pada PAD senilai $\quad 15.389 .749 .772,00$. Terjadi peningkatan kembali yang besar ditahun 2014 dengan kriteria kurang berkontribusi senilai $1,75 \%$ dengan laba senilai 283.193.096,00 dibagi dengan total laba penyertaan modal pada PAD senilai 16.091.497.784,00.

\section{Saran}

Berdasarkan hasil penelitian dan mencermati upaya optimalisasi Laba Perusahaan Daerah Kabupaten Lamongan yang telah di paparkan, maka peneliti memberikan saran sebagai berikut :

1. Perbaikan Kerja BUMD agar lebih profesional dalam menjalankan tugasnya untuk meningkatkan Pendapatan Asli Daerah (PAD).

2. Membemtuk Lembaga Pasar Modal untuk menyediakan dana yang murah dan mudah diperoleh Pemerintah Daerah.

3. Evaluasi secara periodik.

4. Pengawasan secara langsung di lapangan kepada masing-masing Perusahaan Daerah.

5. Memberikan Reward khusus pada Perusahaan daerah dan Perhatian khusus agar Perusahaan Daerah Semakin bersemangat.

6. Melakukan Pembinaan Khusus pada SDM.

7. Perluasan Jaringan dengan stakeholder Perusahaan daerah terutama investor.

8. Melakukan proses penyehatan perusahaan secara menyeluruh dengan meningkatkan kompetensi manajemen dan kualitas SDM.

9. Mengarahkan BUMD untuk dapat berbisnis secara terfokus dan terspesialisasi dengan pengelolaan yang bersih, transparan dan profesional.

\section{Rekomendasi}

Dari kesimpulan diatas, penulis mencoba memberikan rekomendasi sebagai berikut :

\section{PD.Pasar}

Peningkatan pajak dan retribusi pada pasar-pasar di unit-unit dan memonitoring petugas dengan memberikan sangsi tegas pada pihak yang lalai. Untuk bisa menambah pendapatan agar aktiva menjadi lebih 
tinggi atau menjual aktiva yang tidak digunakan, dan kewajiban juga tetap bisa terbayarkan. Pada bagian pembinaan pedagang dan Pendapatan dapat lebih mengkoordinasi terutama pada rekening-rekening yang belum tertagih. Atau untuk meningkatkan profitabilitas dengan menjual aktiva tetap yang dimiliki oleh perusahaan, misalnya dengan menjual mobil dinas yang bukan operasi atau menjual Lamongan Plaza pada investor swasta untuk menambah pendapatan aktiva. Sebab orang Lamongan lebih cenderung memilih pasar Tradisional dibanding Pasar Moderen dengan fakta dilapangan bahwa pengoperasian Lamongan Plaza gagal total, meskipun sudah menarik beberapa investor untuk bekerjasama tapi kenyataannya masih belum berhasil.

\section{DAFTAR PUSTAKA}

Undang-undang No.33 tahun 2004 tentang Perimbangan keuangan antara pemerintah pusat dan daerah

Undang-undang RI No.28 tahun 2009 tentang Pajak daerah dan pendapatan daerah

Nurcholis, Hanif, 2007. Teori dan Praktik Pemerintahan dan Otonomi Daerah. Jakarta : Grasindo.

Mardiasmo, 2002. Otonomi dan Manajemen Keuangan Daerah, Yogyakarta : Andi.

Tangkilisan, dan Hessel N.S. 2005, Manajemen Publik, Jakarta : PT.Grassindo
Susanto A.B, Ghifari A.B, Susanto A, Suradinata E, Wijanarko H, Supranto J, Karmaji, Oyong R, Nurbaya S dan Marth S, 2010, Reinvensi Pembangunan Ekonomi Daerah, Jakarta : Esensi Erlangga Group.

Halim Abdul, Kusufi S.M, 2013, Akuntansi Sektor Publik : Akuntansi Keuangan Daerah, Jakarta : Salemba Empat.

Perda No.5 tahun 2008 tentang PDAM Kab.Lamongan 